\title{
Hai (02) đầu sách tại Thư viện UFM
}

Trung tâm thông tin thư viện

Truy cập:

Ngày 2 tháng 3 năm 2021

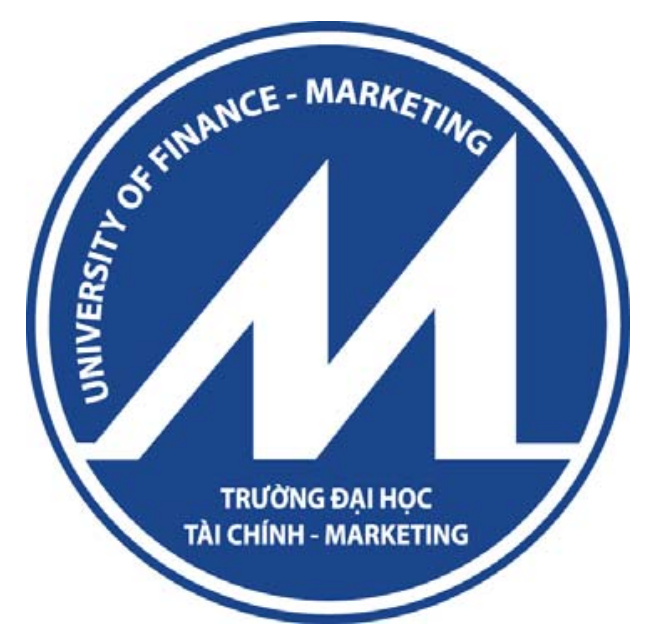

Trường Đại học Tài chính-Marketing (UFM)

Địa chỉ URL:

http://thuvien.ufm.edu.vn/vi/tai-lieu

Hai đầu sách truy xuất được thông tin từ "search" cơ sở dữ liệu:

1. Kinh tế Việt Nam: Thăng trầm và đột phá

Số kiểm soát : 8446

2. Nguyên lý tài chính-toán của thị trường chứng khoán

Số kiểm soát : 25468

Chi tiết thông tin thư viện như trong bản các bản pdf printout từ trang Internet của thư viện UFM bên dưới.

Thông tin trích dẫn trong phần tài liệu tham khảo. 
Tài liệu số

\section{Thông tin}

Số kiểm soát

Số sách chuẩn quốc tế ISBN

Mã ngôn ngữ

Ký hiệu xếp giá theo phân loại thập phân dewey

Tiêu đề chính - Tên cá nhân

Nhan đề chính

Địa chỉ xuất bản, phát hành... (in

ấn)

Mô tả vật lý

Thuật ngữ chủ đề không kiểm soát

Tiêu đề bổ sung - Tên cá nhân

Nơi lưu giữ

\section{Chi tiết}

8446

80.000

vie

$330.09597 \mathrm{~K} 312 \mathrm{~T}$

Phạm Minh Chính

Kinh tế Việt Nam thăng trầm và đột phá / Phạm Minh Chính, Vương Quân Hoàng.

Hà Nội : Tri Thức, 2009

554 tr. : hình vẽ, biểu đồ ; 22 cm

+ Chính sách kinh tế

+ Chứng khoán

+ Điều kiện kinh tế

+ Kinh tế Việt Nam

Vương Quân Hoàng

Kho sách SDH-Phổ Quang SD20001140, SD20001141 
Tài liệu số

\section{Thông tin}

Số kiểm soát

Mã ngôn ngữ

Ký hiệu xếp giá theo phân loại

thập phân dewey

Tiêu đề chính - Tên cá nhân

Nhan đề chính

\section{Chi tiết}

25468

vie

332.642

\section{Vương Quân Hoàng}

Nguyên lý Tài Chính - Toán của Thị trường chứng khoán/ Vương Quân Hoàng, Ngô Phương Trí

H.: Chính, trị quốc gia, 2000

304 tr. $24 \mathrm{~cm}$

Tài Chính ngữ chủ đề

Tiêu đề bổ sung - Tên cá nhân

$$
\begin{aligned}
& \text { + Ngô Phương Trí } \\
& \text { + Vương Quân Hoàng }
\end{aligned}
$$




\section{Tài liệu tham khảo:}

[1] Phạm Minh Chính, Vương Quân Hoàng. (2009). Kinh tế Việt Nam: Thăng trầm và Đột phá. Nxb Chính trị Quốc gia, Hà Nội.

[2] Vương Quân Hoàng, Ngô Phương Chí. (2000). Nguyên lý tài chính-toán của thị trường chứng khoán. Nxb Chính trị Quốc gia, Hà Nội. 